\title{
GROWTH AND BIOPIGMENT ACCUMULATION OF CYANOBACTERIUM SPIRULINA PLATENSIS AT DIFFERENT LIGHT INTENSITIES AND TEMPERATURE
}

\author{
Manoj Kumar, Jyoti Kulshreshtha, Gajendra Pal Singh
}

Department of Botany, University of Rajasthan, Jaipur 302004, INDIA.

Submitted: April 02, 2010; Returned to authors for corrections: November 17; Approved: March 14, 2011.

\begin{abstract}
In order to find out optimum culture condition for algal growth, the effect of light irradiance and temperature on growth rate, biomass composition and pigment production of Spirulina platensis were studied in axenic batch cultures. Growth kinetics of cultures showed a wide range of temperature tolerance from $20{ }^{\circ} \mathrm{C}$ to 40 ${ }^{\circ} \mathrm{C}$. Maximum growth rate, cell production with maximum accumulation of chlorophyll and phycobilliproteins were found at temperature $35^{\circ} \mathrm{C}$ and 2,000 lux light intensity. But with further increase in temperature and light intensity, reduction in growth rate was observed. Carotenoid content was found maximum at 3,500 lux. Improvement in the carotenoid content with increase in light intensity is an adaptive mechanism of cyanobacterium S.platensis for photoprotection, could be a good basis for the exploitation of microalgae as a source of biopigments.
\end{abstract}

Key words: Spirulina platensis, Growth kinetics, Chlorophyll a, Carotenoid, and Phycobiliproteins.

\section{INTRODUCTION}

Microalgae are utilized for the production of several fine chemicals which are either unique to the algae or found at relatively high concentration and command a high market value. In this respect Spirulina is one of the most promising micro-alga. Spirulina is one of the economically important cyanobacterial genus due to its industrial production of proteins, $\beta$-carotene, vitamins (especially B12), phycocyanin and $\gamma$-1inolenic acid (6), and has now become the most wellknown and the most broadly cultivated species of both cyanobacteria and other algae in the world (24).
Spirulina is attracting commercial conglomerates as a source of various nutraceuticals, biomass and pigments $(5,16)$. Among various nutraceuticals, pigments attain growing commercial importance due to their high end applications and easy extraction procedures. Algal cultures are influenced by a variety of environmental factors and they play a significant role in the production and composition of the photosynthetic pigments.

In order to produce high biopigments containing biomass, much attention must be paid to culture status. Large-scale production of Spirulina biomass depends on many factors, the most important of which are nutrient availability, temperature

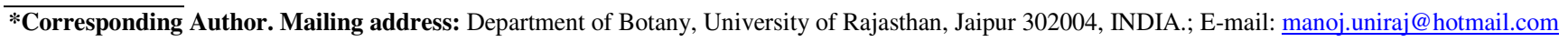


and light (3). There have been several reports relating to the effect of various environmental conditions which influence the growth of Spirulina and the composition of the biomass produced by causing changes in metabolism $(14,23)$.

The objective of the present investigation is to evaluate the influence of different environmental factors i.e. temperature and illumination on the growth and biopigments of Spirulina platensis to optimize the culture condition for its large scale production.

\section{MATERIALS AND METHODS}

\section{Microorganism and Culture condition}

The unialgal culture of cyanobacterium S.platensis (Jal mahal, Jaipur isolate) was grown axenically in batch culture of Zarrouk's media (26). In order to find out the best culture condition for growth and biopigment accumulation in S.platensis, in vitro experiments were carried out. The culture was grown with photoperiod of 12 hours light/dark provided by white fluorescent lamps at a light intensity of 2,500 lux and temperature of $25 \pm 2{ }^{\circ} \mathrm{C}$. Influence of the environmental conditions was studied by varying temperature and light intensity in stepwise individual experiments. Varying light intensities i.e. 500 lux to 4,000 lux were provided by adjusting the light with the help of Lux meter (Lutron LX-101A).

\section{Cultivation}

For the cultivation of S.platensis four days old prepared inoculum of unialgal culture was added to three sets of $500 \mathrm{ml}$ conical flasks containing $250 \mathrm{ml}$ sterilized Zarrouk's medium. To observe the influence of temperature on growth and pigment accumulation, the cultures of S.platensis were grown at different temperatures i.e. $20^{\circ} \mathrm{C}$ to $45^{\circ} \mathrm{C}$ (at $5^{\circ} \mathrm{C}$ interval) at 2,500 lux light intensity. Similarly, the growth of S.platensis was also tested under different light intensities i.e. 500 lux to 4,000 lux (at an interval of 500 lux) at temperature of $25 \pm 2{ }^{\circ} \mathrm{C}$. During the process of growth, the cultures were shaken thrice a day to avoid clumping and accelerate the growth process.

\section{Analytical methods}

Growth was followed through dry weight, optical density and growth rate. Optical density (OD) was recorded with the help of photo-colorimeter at $670 \mathrm{~nm}$ and Spectrophotometer was used for pigment estimation. The chlorophyll a content was estimated by Parson and Strickland (15) method, Carotenoids by Jensen (9), and Bennett and Bogorad's (2) method was used for phycobiliprotein quantitation. Cultures were analyzed for their growth and pigment contents every $5^{\text {th }}$ day.

\section{Statistical analysis}

Results of the analyses were compared by one way analysis of variance (ANOVA). The significance between pairs of variable means were analysed using least significant difference (LSD) test at $5 \%$ level of significance (7).

\section{RESULTS}

\section{Biomass productivity}

Biomass productivity of S.platensis was evaluated at various temperatures and light intensities for a period of 25 days. Growth analysis of cultures grown at different temperatures showed significant difference $(\mathrm{P}<0.05)$ in growth pattern. Maximum biomass concentration (as dry weight) i.e. $0.73 \mathrm{~g} . \mathrm{L}^{-1}$ was observed at temperature $35^{\circ} \mathrm{C}$ and least i.e. 0.26 g. $\mathrm{L}^{-1}$ was found at temperature $20^{\circ} \mathrm{C}$ (Fig. 1). During the growth of cultures, a wide range of temperature tolerance from $20^{\circ} \mathrm{C}$ to $40^{\circ} \mathrm{C}$ was observed. But at $45^{\circ} \mathrm{C}$, the growth was almost negligible (data not recorded). The maximum growth rate i.e. 0.091 doubling day $^{-1}$ was observed at $35^{\circ} \mathrm{C}$, but with further increase in temperature reduction in growth rate was observed. At $40^{\circ} \mathrm{C}$ culture showed 0.041 doubling day ${ }^{-1}$ which is almost half as compared to growth rate at $35^{\circ} \mathrm{C}$ (Fig. 2). 
At different experimental irradiances, 2,000 lux was found to be the optimum light intensity for biomass production. Highest biomass (0.71 g.L $\left.\mathrm{L}^{-1}\right)$, optical density (0.42) and growth rate (0.094 doubling $\left.\mathrm{day}^{-1}\right)$ was found at 2,000 lux light intensity but with further increase in light intensity, reduction in growth rate was observed (Fig. 3, 4, 5).
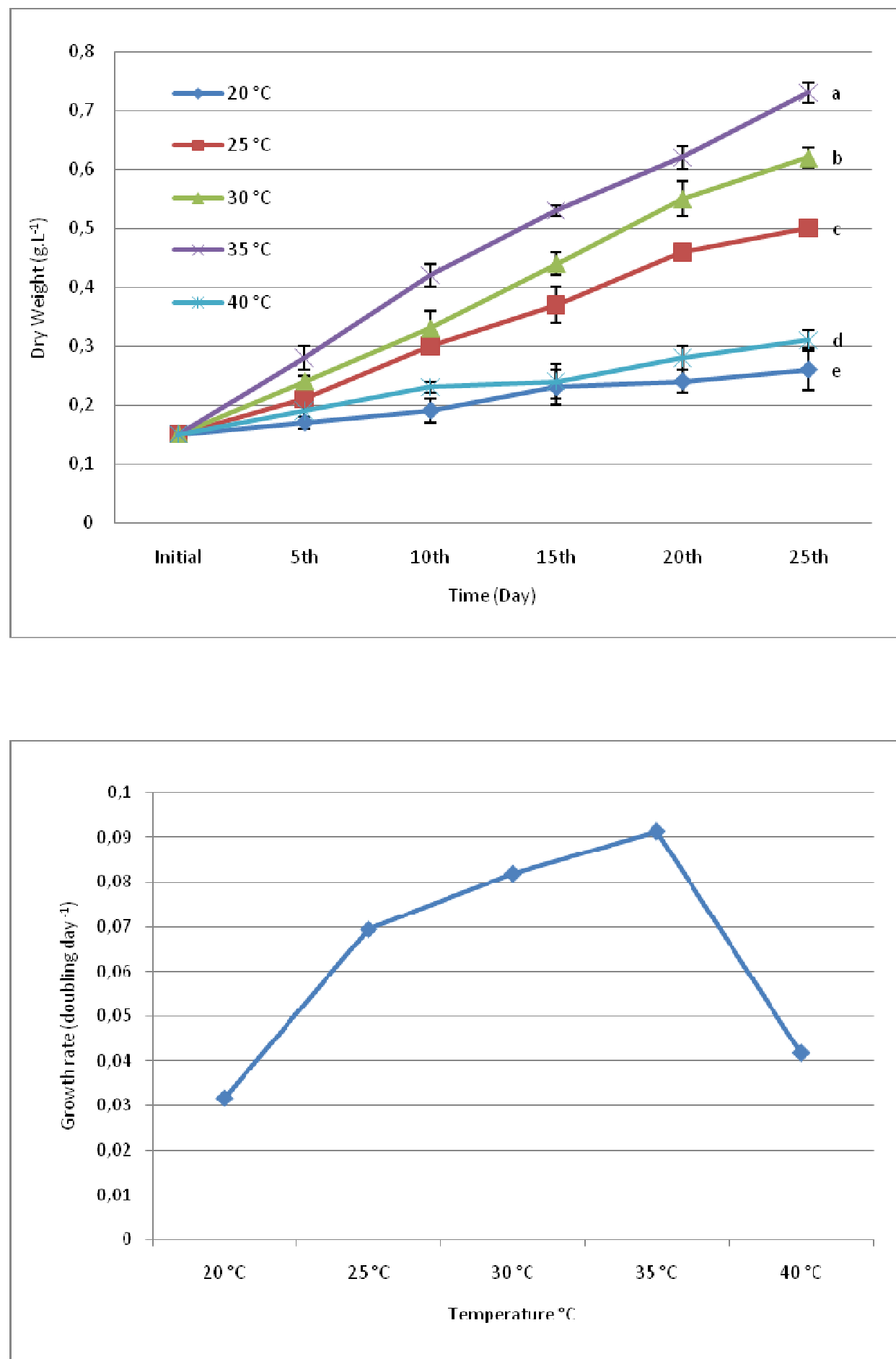

Figure 1. Effect of various temperatures on biomass concentration of S.platensis. Values are means \pm SD $(n=3)$. Variable means with the same letter are not significantly different $(\mathrm{p}>0.05)$.

Figure 2. Effect of different temperatures on growth rate (doubling day ${ }^{-1}$ ) of S.platensis. 


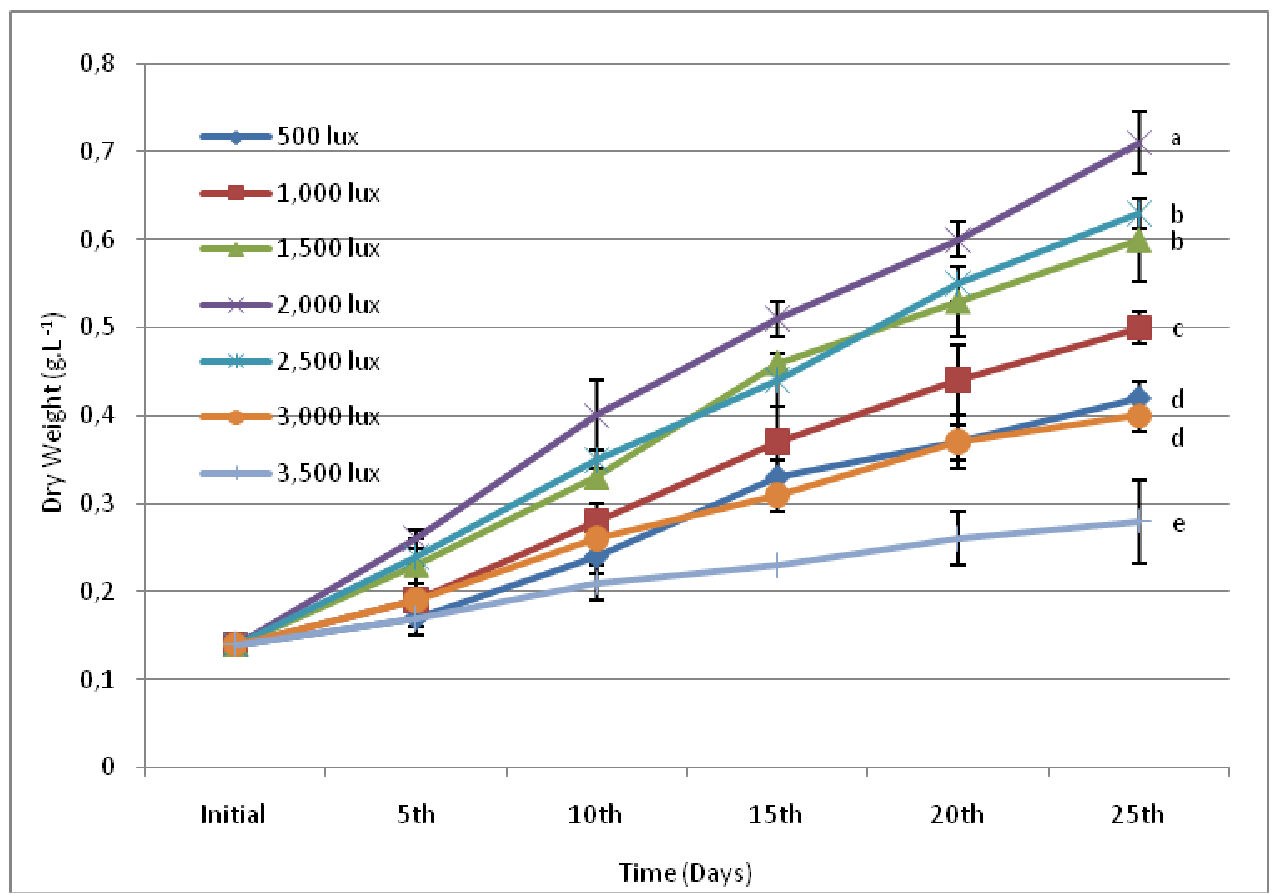

Figure 3. Effect of different light intensities on biomass concentration (dry weight g. $\mathrm{L}^{-1}$ ) of S.platensis. Values are means $\pm \operatorname{SD}(n=3)$. Variable means with the same letter are not significantly different $(\mathrm{p}>$ $0.05)$.

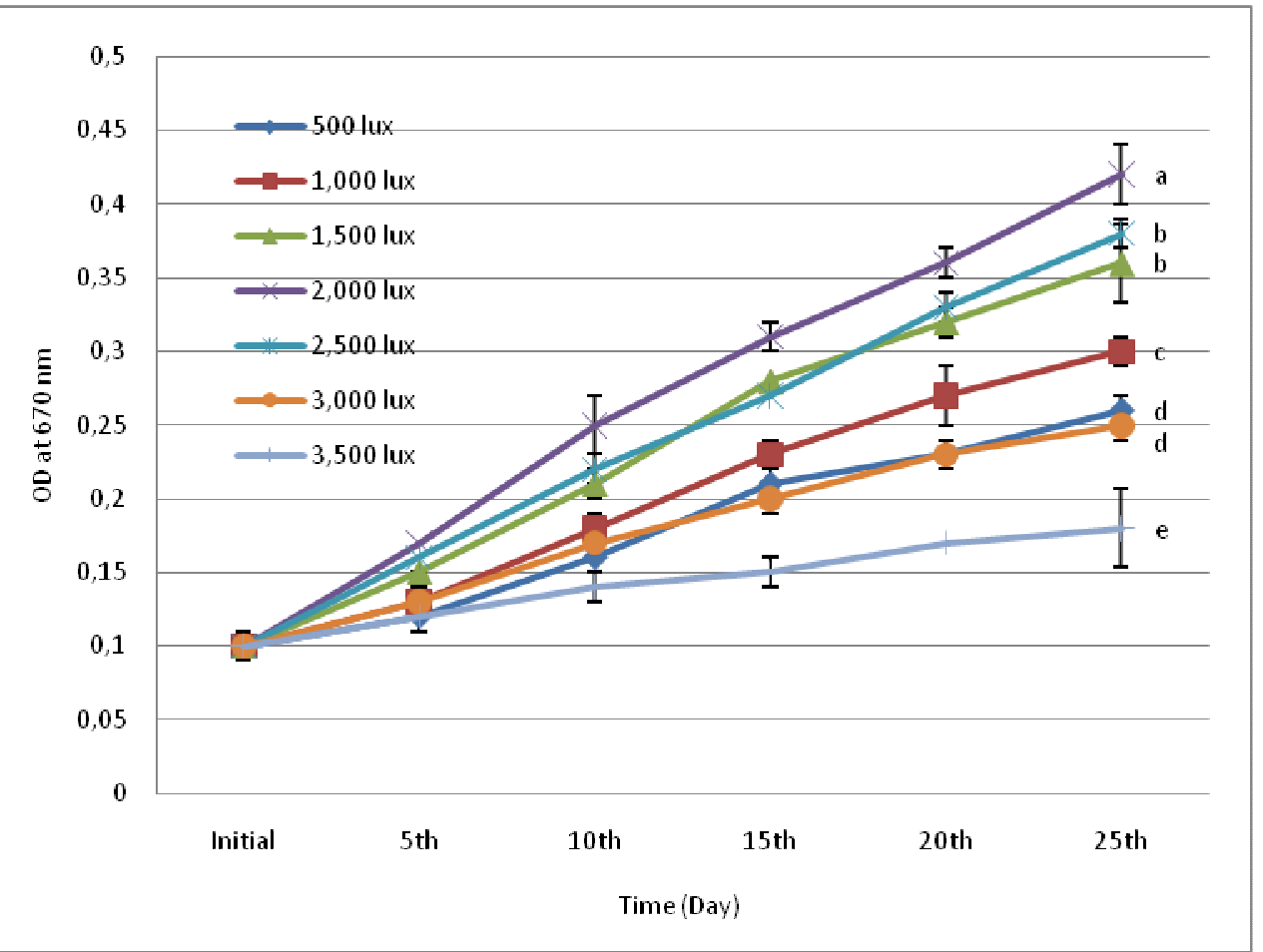

Figure 4. Effect of different light intensities on growth $\left(\mathrm{OD}_{670}\right)$ of S.platensis. Values are means $\pm \mathrm{SD}$ $(\mathrm{n}=3)$. Variable means with the same letter are not significantly different $(\mathrm{p}>0.05)$. 


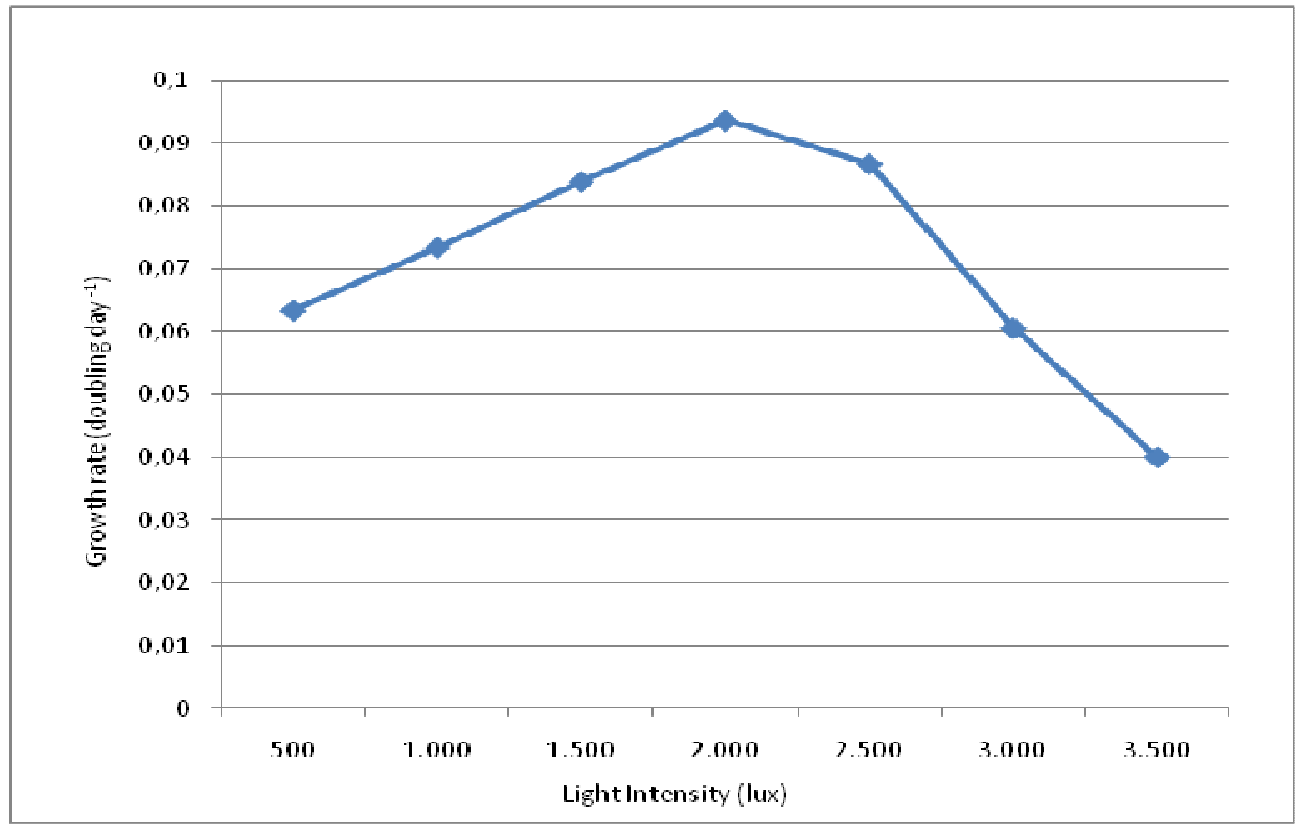

Figure 5. Effect of different light intensities on growth rate (doubling $\left.\operatorname{day}^{-1}\right) \quad$ of $\quad$ S.platensis.

Effect of temperature and light intensity on biopigments of

\section{S.platensis}

Biopigment accumulation at different temperatures: After every $5^{\text {th }}$ day, known amount of cell mass was harvested and analyzed for its pigment contents. At different experimental temperatures up to $35^{\circ} \mathrm{C}$ pigment content gradually increased but with further increase in temperature reduction in pigments was observed. Cultures grown at $35{ }^{\circ} \mathrm{C}$ showed the highest chlorophyll a and carotenoid accumulation i.e. $1.54 \%$ and $0.27 \%$ (of dry weight) respectively (Fig.6). Phycobiliproteins (PBP) were also found maximum in cultures grown at $35{ }^{\circ} \mathrm{C}$ i.e. $7.73 \%$ phycocyanin (PC), $3.46 \%$ allophycocyanin (APC) and $1.798 \%$ phycoerythrin (PE) and minimum was observed at $20{ }^{\circ} \mathrm{C}(5.39 \%$ PC, $2.59 \%$ APC and $0.639 \%$ PE). But the PBP accumulation (except PE) did not show any significant difference $(\mathrm{P}>0.05)$ at temperatures $30^{\circ} \mathrm{C}$ and $35^{\circ} \mathrm{C}$ (Table 1 ).

Table 1. Effect of different temperatures and light Intensities on pigment composition of S.platensis. Values are means \pm Standard deviation $(n=3)$. For each individual experiment variable means with the same letter are not significantly different $(\mathrm{p}>0.05)$. PC Phycocyanin, APC - Allophycocyanin, PE - Phycoerythrin, Chl. a - Chlorophyll a, Cart - Carotenoid.

\begin{tabular}{|c|c|c|c|c|c|}
\hline Temperature & $\mathbf{P C}$ & $\overline{\text { APC }}$ & PE & Cart/Chl. a & PC/ Chl. a \\
\hline $20 \mathrm{C}$ & $5.39 \pm 0.26^{a}$ & $2.59 \pm 0.11^{a}$ & $0.639 \pm 0.014^{a}$ & 0.152 & 4.991 \\
\hline $25^{\circ} \mathrm{C}$ & $6.61 \pm 0.36^{b}$ & $3.07 \pm 0.11^{b}$ & $1.193 \pm 0.010^{b}$ & 0.166 & 5.008 \\
\hline $30^{\circ} \mathrm{C}$ & $7.34 \pm 0.21^{c}$ & $3.32 \pm 0.13^{c}$ & $1.582 \pm 0.013^{c}$ & 0.171 & 5.027 \\
\hline $35^{\circ} \mathrm{C}$ & $7.73 \pm 0.52^{c}$ & $3.46 \pm 0.15^{c}$ & $1.798 \pm 0.017^{\mathrm{d}}$ & 0.175 & 5.019 \\
\hline $40^{\circ} \mathrm{C}$ & $5.59 \pm 0.26^{a}$ & $2.7 \pm 0.14^{\mathrm{a}}$ & $0.786 \pm 0.015^{\mathrm{e}}$ & 0.149 & 4.904 \\
\hline \multicolumn{6}{|l|}{ Light Intensity } \\
\hline 500 lux & $6.125 \pm 0.32^{\mathrm{a}}$ & $2.88 \pm 0.15^{\mathrm{a}}$ & $0.972 \pm 0.006^{\mathrm{a}}$ & 0.158 & 4.940 \\
\hline 1,000 lux & $6.53 \pm 0.35^{a}$ & $3.02 \pm 0.12^{\mathrm{a}}$ & $1.126 \pm 0.015^{b}$ & 0.163 & 5.023 \\
\hline $1,500 \operatorname{lux}$ & $7.05 \pm 0.37^{b}$ & $3.22 \pm 0.09^{b}$ & $1.436 \pm 0.012^{c}$ & 0.169 & 5.000 \\
\hline 2,000 lux & $7.65 \pm 0.35^{c}$ & $3.4 \pm 0.15^{b}$ & $1.7 \pm 0.035^{\mathrm{d}}$ & 0.174 & 5.100 \\
\hline 2,500 lux & $7.255 \pm 0.32^{b c}$ & $3.29 \pm 0.13^{b}$ & $1.527 \pm 0.051^{\mathrm{e}}$ & 0.177 & 5.003 \\
\hline 3,000 lux & $6.1 \pm 0.35^{\mathrm{a}}$ & $2.83 \pm 0.11^{\mathrm{a}}$ & $0.959 \pm 0.017^{\mathrm{a}}$ & 0.178 & 4.959 \\
\hline 3,500 lux & $5.38 \pm 0.42^{d}$ & $2.58 \pm 0.19^{c}$ & $0.63 \pm 0.016^{\mathrm{f}}$ & 0.181 & 4.981 \\
\hline
\end{tabular}




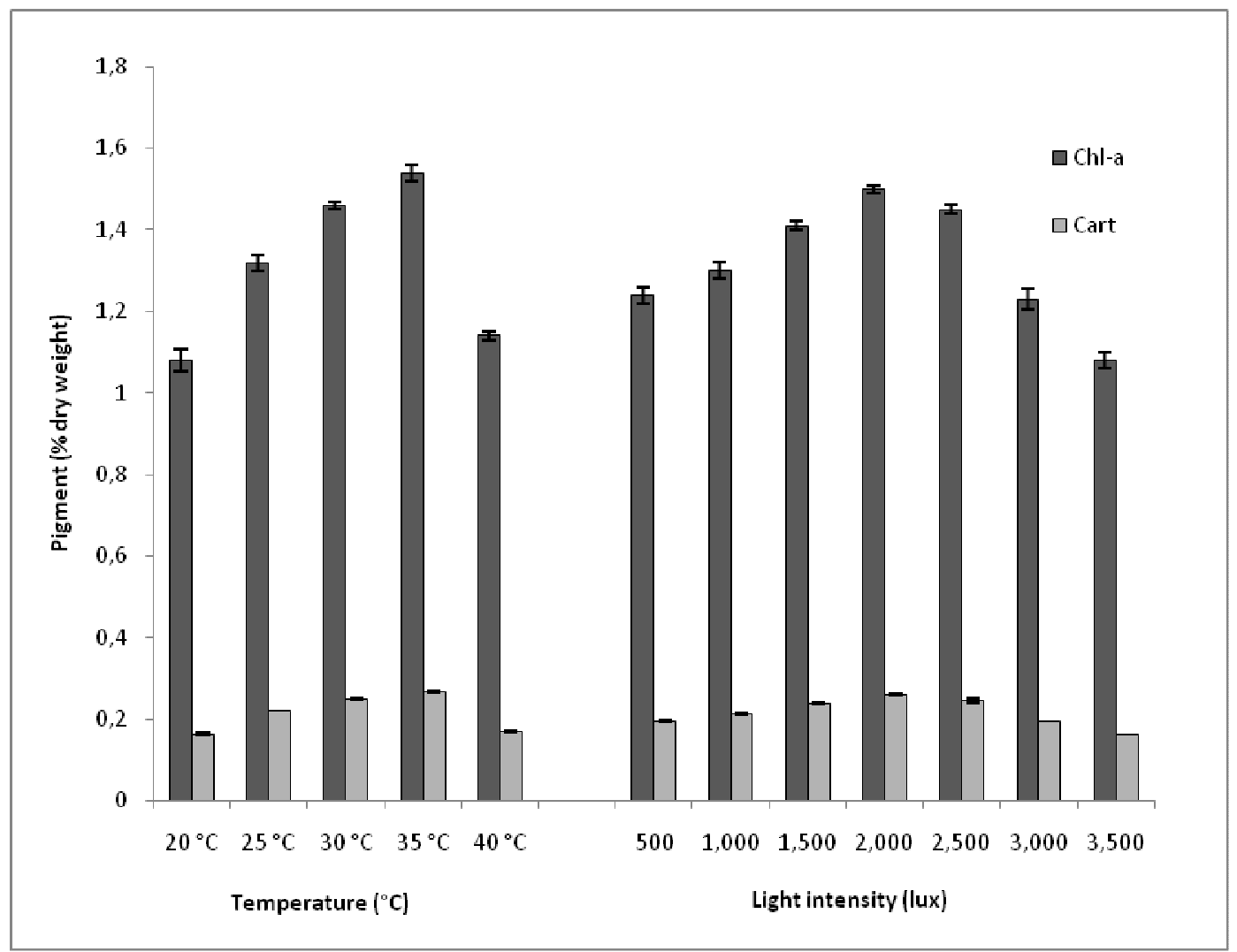

Figure 6. Effect of different temperatures and light intensities on pigments of S.platensis. Values are means $\pm \mathrm{SD}(\mathrm{n}=3)$. Chl. a - Chlorophyll a, Cart Carotenoid.

\section{Biopigment accumulation at different light intensities}

Among various light irradiances tested, 2,000 lux light intensity was found optimum for pigment accumulation. The yield of chlorophyll a was maximum i.e. $1.5 \%$ at 2,000 lux light intensity (Fig. 6). But carotenoid/chlorophyll value (0.181) was found maximum at 3,500 lux. There was an improvement in total carotenoid by increasing light irradiance level (Table 1). Maximum PBP accumulation was found at 2,000 lux light intensity, but increase in light irradiance showed reduction in PBP production. Cultures receiving 2,000 lux had 7.65 \% PC, $3.4 \%$ APC and $1.7 \%$ PE and significantly $(\mathrm{P}<0.05)$ least PBP (i.e. $5.38 \%$ PC, $2.58 \%$ APC and $0.63 \%$ PE) was found in cultures irradiated with 3,500 lux light intensity. At 2,000 and 2,500 lux light intensity no significant difference observed for PC and APC accumulation, but 2,500 lux showed the significant reduction in PE, so 2,000 lux was found optimum light intensity for PBP accumulation (Table 1).

\section{DISCUSSION}

Growth analysis of cultures grown at different temperatures showed different growth patterns. Maximum growth rate and biomass concentration were observed in cultures receiving $35^{\circ} \mathrm{C}$ temperature. Growth curve of cultures at various temperatures revealed that S.platensis has a wide range of temperature tolerance from $20^{\circ} \mathrm{C}$ to $40^{\circ} \mathrm{C}$. Cultures at $20^{\circ} \mathrm{C}$ and $40^{\circ} \mathrm{C}$ did not show exponential growth, which proved that extreme temperatures did not support the growth of S.platensis (Fig. 1). But at $45^{\circ} \mathrm{C}$ temperature, the absence of growth was observed with the disappearance of pigmentation. Growth rate of S.platensis increased with increase in temperature and was found maximum at temperature $35^{\circ} \mathrm{C}$. Increased growth rate of S.platensis was due to decrease in doubling time. Later it drops with further increase in temperature due to decrease in chlorophyll and other pigments. 
Similar observations were also reported by many other workers, Ranjitha and Kaushik (17) reported that the highest biomass in Nostoc muscorum was obtained at $30^{\circ} \mathrm{C}$ and $35^{\circ} \mathrm{C}$. According to Richmond (18), from observations of different strains of Spirulina, the optimal growth temperature was between $35^{\circ} \mathrm{C}$ and $37^{\circ} \mathrm{C}$ with $40^{\circ} \mathrm{C}$ being definitely injurious. In addition, Ronda and Lele (19) and Ogawa et al. (13) reported similar observations for optimum temperature of S.platensis. Earlier reports of Srivastava (22), Bajaj (1) and Singh and Srivastava (21) confirm these observations. Temperature is the most fundamental factor for all living organisms as it affects metabolic processes and biochemical composition of cells. The optimal growth temperature and tolerance to the extreme values usually vary from strain to strain.

Chlorophyll a, carotenoid and phycobiliprotein were also found maximum in cultures growing at temperature $35{ }^{\circ} \mathrm{C}$. PC/Chl. a value indicates that depending on extent of temperature there was decrease in PC accumulation. This decrease in the PC could be due to the bleaching of PBP. In the present study, optimum temperature for phycobiliprotein was $35^{\circ} \mathrm{C}$ (Table 1). Other workers have reported $37^{\circ} \mathrm{C}$ as optimum for Arthronema africanum (4), $36^{\circ} \mathrm{C}$ for Synechococcus (20) and $25^{\circ} \mathrm{C}$ for red algae Audoinella pygmaea, Batrachospermum delicatulum and Comsopogon coureuleus (27).

The growth rate, biomass production and biopigment accumulation of S.platensis at different experimental irradiances showed 2,000 lux as the optimum light intensity. Further increase in light intensity shows reduction in growth due to drop in chlorophyll a synthesis. But the carotenoid/chlorophyll value shows the maximum accumulation of carotenoid at 3,500 lux light intensity. Improvement in the carotenoid content by increasing the light intensity is an adaptive mechanism by the organism for photoprotection. S.platensis was also reported to display increased carotenoid levels under strong illumination by Liu (11) and in astaxanthin-accumulating algae Haematococcus pluvialis by Kobayashi et al. (10). PBP also show decreased value with increase in light irradiance. It has been suggested that cyanobacteria prefer low light intensities and stimulate phycobiliprotein synthesis (8) because of their low specific maintenance energy rate and their pigment composition (12). Not only this, low irradiances actually broadens the overall light absorption band in such a way that the balance of light energy distribution between the two photo systems is maintained this optimizes the rate of light energy conversion (25).

On the basis of our findings we concluded that the maximum biomass production with high pigment contents in S.platensis were shown by cultures receiving $35^{\circ} \mathrm{C}$ temperature and 2,000 lux light intensity. S.platensis has a wide range of temperature tolerance from $20^{\circ} \mathrm{C}$ to $40^{\circ} \mathrm{C}$ with different growth rates. High light intensity also helps in improvement of carotenoid level in S.platensis for photoprotection which could be a good basis for the exploitation of S.platensis as a source of biopigments.

\section{REFERENCES}

1. Bajaj, V. (1986). The effect of antibiotics and mutagenic chemicals on certain members of green Algae- Scendesmus spp. Jaipur, India. ( $\mathrm{PhD}$ Thesis, University of Rajasthan, Jaipur).

2. Bennett, A.; Bogorad, L. (1971). Properties of subunits and aggregates of blue-green algae biliproteins. Biochem. 10, 3625-3634.

3. Carvalho, A.P.; Malcata, F.X. (2003). Kinetic modeling of the autotrophic growth of Pavlova lutheri: study of the combined influence of light and temperature. Biotechnol. Prog. 19, 1128-1135.

4. Chaneva, G.; Furnadzhieva, S.; Minkova, K.; Lukavsky, J. (2007). Effect of light and temperature on the cyanobacterium Arthronema africanum a prospective phycobiliprotein producing strain. J. Appl. Phycol. 19, 537544.

5. Ciferri, O.; Tiboni, O. (1985). The biochemistry and industrial potential of Spirulina. Annu. Rev. Microbiol. 39, 503-526.

6. Cohen, Z. (1997). The chemicals of Spirulina. In: Vonshak A (eds) Spirulina platensis (Arthrospira): physiology, cell-biology and biotechnology. Taylor and Francis, USA, p. 175-204.

7. Gomez, K.A.; Gomez, A.A. (1984). Statistical procedures for 
agricultural research. John Wiley and Sons, Inc., New York, p. 680.

8. Grossman, A.R.; Schaer, M.; Chiang, G.; Collier, J. (1993). Environmental effects on the light harvesting complex of cyanobacteria. J. Bacteriol. 175, 575-582.

9. Jensen, A. (1978). Chlorophylls and carotenoids. In: Hellebust JA, Craigie JS (eds) Handbook of phycological methods, physiological and biochemical methods. Cambridge University Press, Cambridge, p. 59-70.

10. Kobayashi, M.K.; Toshihide, N.M.; Nagai, S. (1992). Effects of light intensity, light quality and illumination cycle on astaxanthin formation in a green alga, Haematococcus pluvialis. J. Ferment. Bioeng. 74, 61-63.

11. Liu, H.I. (1984). Effects of temperature and light intensity on growth rate, physiological and biochemical characteristics of Spirulina platensis. Zhonghua Nongye Yanjiu 33, 276-291.

12. Mur, L.R.; Elema, R.P. (1983). The influence of light quality on the growth of some phytoplankton species. Laboratory of Microbiology, University of Amsterdam, Niewe Achtergracht 127, 1018 WS, Amsterdam, The Netherlands.

13. Ogawa, T.; Kozasu, H.; Terui, G. (1971). Studies on the growth of Spirulina platensis II. Growth kinetic of an autotrophic culture. J. Ferm. Tech. 50, 143-149.

14. Olguin, E.J.; Galicia, S.; Angulo-Guerrero, O.; Hernandez, E. (2001). The effect of low light flux and nitrogen deficiency on the chemical composition of Spirulina sp. (Arthrospira) grown on digested pig waste. Bioresour. Technol. 77, 19-24.

15. Parson, T.R.; Strickland, J.D.H. (1965). Particulate organic matter III. I. pigment analysis III, I.I. Determination of Phytoplankton pigments. $J$. Fish. Res. Bd. Canada 18, 117-127.

16. Pulz, O.; Gross, W. (2004). Valuable products from biotechnology of microalgae Appl. Microbiol. Biotechnol. 65, 635-648.

17. Ranjitha, K.; Kaushik, B.D. (2005). Influence of environmental factors on accessory pigments of Nostoc muscorum. Indian J. Microbiol. 45 (1),
67-69.

18. Richmond, A. (1988). Spirulina. In: Micro-algal Biotechnology, Cambridge University Press, Cambridge. p. 85-121.

19. Ronda, S.R.; Lele, S.S. (2008). Culture conditions stimulating high $\gamma$ Linolenic acid accumulation by Spirulina platensis. Braz. J. Microbiol. 39, 693-697.

20. Sakamoto, T.; Bryant, D.A. (1998). Growth at low temperature causes nitrogen limitation in the cyanobacterium Synechococcus sp. PCC 7002. Arch. Microbiol. 169, 10-19.

21. Singh, G.P.; Srivastava, P. (1991). Impact of varied culture conditions on growth and morphology of Ankistrodesmus fusiformis. J. Indian Bot. Soc. 71, 341-345.

22. Srivastava, P. (1967). Studies on the experimental cultures of certain Chlorococcales. PhD Thesis, Osmania Univerisity Hyderabad, India.

23. Volkmann, H.; Imianovsky, U.; Oliveira, J.L.B.; Sant'Anna, E.S. (2008). Cultivation of Arthrospira (Spirulina) platensis in desalinator wastewater and salinated synthetic medium: protein content and amino-acid profile. Braz. J. Microbiol. 39, 98-101.

24. Vonshak, A. (1997). Use of Spirulina biomass. In: Vonshak A (eds) Spirulina platensis (Arthrospira): physiology, cell-biology and biotechnology. Taylor and Francis, USA, p. 205-212.

25. Wyman, M.; Fay, P. (1986). Underlight water climate and the growth and pigmentation of planktonic blue green algae (cyanobacteria). I. The influence of light quantity. Proc. R. Soc. Lond. B. 227, 367-380.

26. Zarrouk, C. (1966). Contribution a l'etude d'une cyanophycee. Influence de divers facteurs physiques et chimiques sur la croissance et photosynthese de Spirulina maxima (Setch et Gardner) Geitler. PhD Thesis, University of Paris, Paris, France, p. 4-5.

27. Zucchi, M.R.; Neechi, O. (2001). Effects of temperature, irradiance and photoperiod on growth and pigment content in some fresh water red algae in culture. Phycol. Res. 49, 103-114. 